\title{
Servant Leadership: The Exemplifying Behaviours
}

\author{
Mrs Wekesa S. Olesia ${ }^{1}$, Prof. G.S. Namusonge ${ }^{2}$, Dr. Mike A. Iravo ${ }^{3}$ \\ ${ }^{1}$ Ph.D Candidate (Corresponding Author) Jomo Kenyatta University of Agriculture and Technology, \\ Department of Entrepreneurship and Procurement, P. O. Box 62000-00200 Nairobi, Kenya. \\ ${ }^{2}$ Jomo Kenyatta University of Agriculture and Technology, Department of Entrepreneurship and Procurement \\ P.O. Box 62000-00200 Nairobi, Kenya. \\ ${ }^{3}$ Jomo Kenyatta University of Agriculture and Technology, Department of Entrepreneurship and Procurement \\ P.O. Box 62000-00200 Nairobi, Kenya
}

\begin{abstract}
Over the years, there has been a keen concern to understand behaviours that leaders can adopt in order to lead and influence others to achieve agreed upon goals. Servant leadership is one of the emerging contemporary leadership styles that are receiving a lot of attention. This has been occasioned by a world wide desire for more ethical and caring leadership in organizations. This leadership style has been adopted by some of the best companies in the world with great success. The purpose of this paper is to highlight some of the very exemplifying behaviours of servant leaders, which if embraced by modern leaders can greatly enhance the motivation, commitment and performance of employees for increased productivity.
\end{abstract}

Key Words: Empowering and Developing Others, Humility, Role Modeling, Servant Leadership, Service Orientation, Visioning

\section{Introduction}

Leadership is without a doubt important and its demand has increased greatly in recent years, especially in organizations (Drucker, 1995 as cited in Stefánsdóttir, 2013). Despite having been studied for decades, leadership still remains an important concept that continues to receive considerable interest in management literature. Leadership is a social influence process in which the leader seeks the voluntary participation of subordinates in an effort to reach organization goals. It is a process whereby one person exerts social influence over other members of the group (Bamigboye, 2000; Omolayo, 2000 as cited in Akinola \& Olumide, 2011). Effective leadership is very important to the success or failure of any organization (Yong, 2013).

There is still an upsurge of interest in the characteristics or behaviours that define a good leader. It is for this reason that leadership theories have continued to evolve over the years. Most recently, there has been considerable interest in leadership theories such as transformational, transactional and servant leadership. Leadership style can be regarded as patterns that are regarded desirable and displayed by leaders in the process of influencing and directing employees. They are the behaviors that managers exhibit when confronting with employees (Shiri et al, 2014). Managers will usually display different kinds of behaviours when interacting with employees with varying degrees of success. However, whichever way leadership and its pattern is defined, one thing that is certain and generally acknowledged among scholars is that from time immemorial, the role of leaders in ensuring excellent organizational performance and workers commitment to work cannot be over emphasized ( Akinola \& Olumide, 2011).

\section{Servant Leadership}

Servant leadership is one of the emerging theories of leadership and it is very different from the traditional trait, behavioural and situational theories. Coinciding with business interest in a more caring and responsible style of leadership, organizational scholars have shifted their attention away from leadership based on individualistic, self-serving tendencies towards more relational styles of leadership (Avolio et al, 2009 as cited in Peterson \& Galvin, 2012). There has been tremendous conceptual and empirical research that has focused on servant leadership (Peterson \& Galvin, 2012). It is a leadership style that transcends self-interest to serve the needs of others by helping them grow professionally and personally (Lussier \& Achua, 2007 as cited in Carder, 2012).

Servant leadership as first proposed by Greenleaf (1970) is a theoretical framework which stipulates that a leader's primary motivation and role is service to others. Greenleaf first coined this modern term servantleadership in 1970 in the essay entitled, The Servant as Leader (Spears, 1996). According to Greenleaf, servant leadership begins with the natural feeling that one wants to serve, to serve first then conscious choice causes one to aspire to lead (Greenleaf, 1991). Greenleaf was inspired to write about servant leadership when he read the book entitled The Journey to the East by Herman Hesse. The book is about a band of men on a spiritual journey. 
The main character in the book is Leo, who is their servant. Leo is not only their servant, but he sings for them and maintains their spirits as well. When Leo disappears, the group falls apart and abandons the journey. When the narrator of the story meets the group again later on, he realizes that Leo was in fact, the leader of the group, although he was also serving them. Hence, Leo is depicted first as a servant and then later on as leader and this is the essence of servant leadership.

\section{Theoretical Framework}

Servant leadership is a type of leadership which comes under the democratic style. Leader and servant are opposite terms but the practice of servant leadership takes place when the characters of these two opposite terms are used simultaneously in an individual's leadership style. In servant leadership, a leader is called to serve the group members or followers while leading them. This theory advocates that a leader's primary motivation and role is to serve and meet the needs of others, which optimally should be the prime motivation for leadership (Russell \& Stone, 2002). Greenleaf attached great significance to this idea that true leadership carries with it the responsibility of first seeking to serve others. He says that true leadership emerges from those whose primary motivation is a deep desire to help others. It aims at putting the well-being of the followers before other goals (Greenleaf (1977). Servant leaders develop people, helping them to strive and flourish (McMinn, 2001).

Servant leadership is a belief that organizational goals will be achieved on a long term basis only by first facilitating the growth, development and general well-being of the individuals who comprise the organization (Stone et al, 2003). It is therefore a leadership style that emphasizes that leaders should be attentive to the concerns of their followers and empathize with them; they should take care of them and nurture them (Northouse, 2007). The best test of the leader is whether those served grow as persons and whether while being served they become healthier, wiser and more able themselves to become servant leaders (Wheeler, 2011). Servant leadership theory as an ethical style in leadership and management is quite important among leadership styles and can be regarded as one of the ideal styles in managing human resources (Mazarei et al, 2013)

\section{Servant Leadership Themes}

Servant leadership themes have been discussed by various authors in the recent years. Laub (1999) developed a conceptual model consisting of six servant leadership characteristics which include; develops people, valuing people, building community, displaying authenticity, providing leadership and sharing leadership. Page \& Wong (2000) identified the following attributes; integrity, humility, servanthood, caring for others, empowering others, developing others, visioning, goal setting, leading, modeling, teambuilding and shared decision making

Russell \& Stone (2002) identified these attributes; Vision, modeling, communication, persuasion, honesty, pioneering, credibility, listening, integrity, appreciation, competence, encouragement, trust, empowerment, stewardship, service, delegation, visibility and influence. Patterson (2003) came up with a model which comprises of seven dimensions of agapao love, humility, altruism, vision, trust, empowerment and service.

Spears (2004) listed ten characteristics that he perceived servant leaders portrayed and they are; listening, empathy, healing, awareness, persuasion, conceptualization, foresight, stewardship, commitment and building society. Enrhart (2004) identified major behaviours of servant leaders as forming relationships with subordinates, empowering subordinates, helping subordinates grow and succeed, behaving ethically, having conceptual skills, putting subordinates first and creating value for those outside the organization.

Liden et al (2005) identified emotional healing, creating value for the community, conceptual skills, empowering, helping subordinates grow and succeed, putting subordinate first and behaving ethically. Parolini (2005) further identifies servant leadership as valuing people, building relational and authentic community and providing and sharing leadership. Barbuto and Wheeler (2006) have proposed five dimensions of servant leadership which include altruistic calling, emotional healing, wisdom, persuasive mapping and organizational stewardship.

\section{Exemplifying Servant Leadership Behaviours}

Despite the vast array of terms used to describe servant leadership, the major descriptors that are consistently mentioned are, leading by example, service, vision and also humility (Hale \& Fields, 2007). A servant leader has true commitment to his or her followers and predominantly serves the needs of followers, hence providing vision and empowerment, with service being the main activity of the servant leader (Sendjaya \& Sarros, 2002; Stone et al, 2004; Spears, 2010 in Mahembe \& Engelbrecht, 2013). The following is a discussion of these distinctive servant leadership behaviours as described by various writers.

\section{Humility}

According to Collins (2001), organizations do not only need to be good today in order to survive, but great, and a fundamental ability in building great companies is displaying humility as well as strength. 
Interestingly, humility is one of the main characteristics of the emerging people-centered leadership theory, servant leadership (Greenleaf, 1970; Dierendonck \& Nuijten, 2011 as cited in Stefansdottir, 2013). Humility is an attitude and acknowledgment by the servant leader that they are neither omniscient nor omnipotent, and that employee's may have more knowledge and experience. Ferch (2005) argued, "one of the defining characteristics of human nature is the ability to discern one's own faults, to be broken as the result of such faults, and in response to seek a meaningful change". Patterson (2003) described humility in leadership as a leader's ability to grasp the idea of not knowing, understanding, or having all the answers. Such a conceptualization of humility is foundational to leader self-evaluation. For servant leaders in organizations dependent on knowledge workers, this is especially important as it is highly probable that employees do indeed know more about their specialization than anyone else inside the company. Indeed, humility is also about modesty and it is for this reason that a servant leader retreats into the background when a task has been fully accomplished (van Dierendonck, 2010). By acknowledging fallibility and the limits of one's own knowledge, the servant leader helps to facilitate a learning environment in which employees can learn and develop through their own experimentation and by learning from others. Many studies have lent credibility to this servant leadership behavior (Patterson, 2002; Sendjaya, 2003; Dennis \& Bocarnea, 2005; Sendjaya et al , 2008; Ambali et al , 2011; Mazarei et al, 2013; Taleghani \& Mehr, 2013).

\section{Service Orientation}

The virtue of service is at the core of the servant leadership model (Patterson, 2003). Servant leaders imbue the meaning of and reinforce the importance of serving others within and outside the organization through their behavior, which provides crucial cues that serving others is a distinctive characteristic of the organization (Zhang et al, 2012). According to Spears (2004) a great leader is first experienced as a servant by others including employees, customers and community as the number one priority. A leader's fundamental desire is to first help others and servant leadership begins when a leader assumes the position of servant in his or her interactions with followers. Servant leaders are first and foremost servants at heart and are called to a life of service, thus servant leaders choose to lead based on the interest of others, as opposed to self-interest (Russell \& Stone, 2001; Patterson, 2003). Servant leadership is not much about leading but about serving as a leader (Sendjaya \& Peckerti , 2010 as cited in Taleghani \& Mehr, 2013).

Servant leaders model service through their own behaviour thus cultivating an organizational culture of service that inspires and motivates followers (Patterson, 2003). Leaders understand that service is the centre of servant leadership and they should emulate a service model for the follower in their behaviour, attitudes and values (Russell \& Stone, 2002; Winston, 2003). Servant leaders are therefore follower focused and their main aim is to serve others and fulfil their needs (Parolini et al, 2009 as cited in Wei \& Desa, 2013). Greenleaf (1970) wrote and said that this simple fact is the key to leader greatness. Amy (2012), states that Greenleaf gave significant weight to the idea that true leadership carries a responsibility to think first about being of service to others. When a leader puts the interests of the followers first before his or her own self-interests, it brings out the best in the employees who will then exhibit higher levels of organizational commitment. According to van Dierenndonck and Patterson (2010) as cited in Wei and Desa (2013), the servant leader's nature of serving others helps to produce an environment of cohesion, concern and trust. Unlike other leadership styles, servant leadership therefore prioritizes other's needs over their own (Mazarei et al, 2013).There are quite a number of empirical studies that have supported this servant leadership behaviour (Farling et al, 1999; Page \& Wong, 2000 Dennis \& Winston, 2003; Hale \& Fields, 2007; Patterson, 2002; Russell \& Stone, 2002; Mazarei et al, 2013; Taleghani \& Mehr, 2013).

\section{Visioning}

This servant leader behaviour entails having foresight. Foresight needs to be combined with the ability to communicate the vision to and influence followers in and developing a shared vision for an organization (Hale \& Fields, 2007). The central role of the servant leader is establishing a strategic vision for the organization (Covey, 1996; De Pree, 1997; Maxwell, 1998 in Russell \& Stone, 2002). In the visionary role, leaders are expected to define the direction of the organization and they need to communicate what the organization stands for and how organizational values encompass the individual values of its members (Blanchard, 2000). When it comes to vision and values, the leader has to say it over and over and over again until people get it right (De Pree, 1997). In order for the vision to have impact on the employees, it must be communicated to them effectively so that they are in a position to understand how they fit in this future envisaged state. Lubin (2001) maintained that the leaders job is to encourage people to share their good ideas to eventually create a shared vision that everyone cares about. Taylor (2002) concurs by stating that the mark of a leader and the attribute that puts him or her in a position to attract followers is when the leader demonstrates the ability to see more clearly the best destination for the organization. 
Servant leaders must dream while remaining in the past and focused on the future because this allows the leader to take advantage of the opportunities of the present (Bennett, 2001). Servant leader's advance shared vision through personal example and appealing to higher ideals such as serving the community. This shared vision inevitably leads to teamwork. In servant leadership, employees will usually be driven by an inner motivation to attain the vision of the organization. The servant leader will engage all of them and inspire each of them to stretch and use whatever talents they have in order to attain this shared vision (Page \& Wong, 2000). Employees who understand and participate in the organization's vision are inspired, energized and feel ownership of that vision and the decisions management makes as a result of the vision. When employees own the vision of the organization, they are motivated to work towards the realization of that vision which in turn will cause them to be committed to the organization they work for. Empirical studies have supported this variable (Russell \& Stone, 2002; Dennis \& Winston, 2003; Hales \& Fields, 2007; Budwest \& Bocarnea, 2008)

\section{Empowering and Developing Others}

Empowerment is a major factor in servant leadership and should be one of its primary focus (Russell \& Stone, 2002). Patterson (2003) concurs by stating that empowering people, with the best interest of those served in mind is at the heart of servant leadership. She further asserts that it is entrusting power to others and really giving it away. It is letting people to do their jobs by enabling them to learn, grow and progress and as such it means allowing for self-direction and freedom to fail and this multiplies the follower's strengths and trust (Patterson, 2003).

Empowering and developing people is about giving people in the workplace responsibility for their own actions. Through empowerment, the servant leader acknowledges the talents and strengths of employees. In addition, the servant leader must encourage employees in their actions and in their personal growth. Underlying empowerment is the acknowledgment that employees are not merely subordinates, but that each is an individual in their own right (van Dierendonck, 2011). Empowering employee's means employees are assuming roles that were previously the domain of management such as the assignment of tasks, ordering materials, and even disciplining co-workers. Empowered employees share in both planning and decision making which will ultimately lead to more decentralized organizations that embrace power sharing (van Dierendonck, 2011). This empowerment of followers is progressive in nature, allowing the follower to learn and grow until he or she is capable and willing to handle larger levels of empowerment (Winston, 2003). Quite a number of empirical studies have studied, supported and lent credibility to this servant leadership behavior (Page \& Wong, 2000; Patterson, 2002; Russell \& Stone, 2002; Sendjaya, 2003; Dennis \& Winston, 2003; Erhart, 2004; Dennis \& Bocarnea , 2005; Liden et al , 2008; Sendjaya et al, 2008; Earnhardt; 2008).

\section{Role Modeling}

Modeling in the form of a visible personal example is an important component of servant leadership (DePree, 1992; Kouzes \& Posner, 1993; Bennis \& Nanus, 1997 as cited in Russell \& Stone, 2002). Modeling is the principle way through which a leader can influence the followers. Leaders model the way through personal example and dedicated execution. Modeling provides an example and demonstrates the behaviour that the leader is seeking from others. Servant leaders model examples that can be emulated by others.

Authentic leaders model what matters and are willing to practice what they preach when it comes to expected organizational behaviour. Modelling what matters is the primary and most effective way to communicate the organization's mission, values, and ethos and that action communicates much more loudly than words when it comes to organizational values. Effective leaders also instil values through deeds as much as or more than through words (Malphurs, 1996 as cited in Russell \& Stone, 2002). In order to support this leadership practice, DePree (1992) argues that clearly expressed and consistently demonstrated values are often the most important factor in facilitating the important relationship between leaders and followers. Servant leaders attract followers by their example so that they become more committed, dedicated and even disciplined. The behaviours of senior leaders also establish the ethical tone of their organizations (Kouzes \& Posner, 1993). Servant leaders model servant behaviours such as helping with housekeeping or setting up for meetings. They work side-by-side while serving with others in and around the organization (Ehrhart, 2004 as cited in Ebener \& O'Connell, 2010). There are empirical studies that have studied and supported this role modeling behaviour (Russell \& Stone, 2002; Page \& Wong, 2000)

\section{Servant Leadership Versus Other Leadership Styles}

Servant leadership distinctively stands out from other leadership styles. While most traditional leadership theories are behaviorally based, servant leadership emerges from a leader's principles, values, and beliefs (Walker, 2003). At the same time, most types of leadership concentrate on the well being of the organization while in servant leadership the focus is on followers who are considered to be the most important (Kool \& Dierendonck, 2012 as cited in Taleghani \& Mehr, 2013). Servant leadership focuses on the humble and 
ethical use of power, cultivating a genuine relationship between leaders and followers and creating a supportive and positive work environment (Wong \& Davey, 2007). The focus of the servant leader is on meeting the needs of the employees and not on fulfilling the leader's needs. It is a leadership style that places great emphasis on the personal development and empowerment of followers (Thakore, 2013).

Servant leadership thus comprises an understanding and practice of leadership that places the good of those who are led above the self-interest of the leader. Today, the success of organizations and companies is greatly determined by people oriented leadership style and it is no wonder that servant leadership is gaining a lot of prominence in the recent years. Servant leaders gain influence in a non-traditional manner that derives from servant hood itself (Russell \& Stone 2002 in Stone et al, 2004). The main focus of servant leadership is on the service of people rather than control or self-interest. It is not much about leading but about serving as a leader (Sendjaya \& Peckerti, 2010 as cited in Taleghani \& Mehr, 2013). However, in terms of the actual exercise of leadership, servant leaders are free to incorporate the positive aspects of all other leadership models except command and control dictatorial leadership style (Wong \& Davey, 2007). Servant leaders are free to be flexible and situational (Wong, 2003).

\section{Conclusion}

Servant leadership is the key to a better world that people are in dire need of. One that is freer, healthier, more humane and more prosperous. In view of the current demand for more ethical, people - centred management, leadership inspired by the ideas from servant leadership theory may very well be what organizations need now. This is because it is a leadership style that is good for the leader as well as the led because it is ethical, practical and a meaningful way to live and be led. This leadership style has been found to be positively related to trust, organizational citizenship behaviours, procedural justice, extra effort, organizational commitment, follower need fulfilment and a promotional mindset. Servant leadership is therefore a leadership style that should be embraced by today's organizations in order to enhance employee loyalty, commitment and performance.

\section{References}

[1.] Akinola, G. D \& Olumide,O. (2011) Evaluation of Leadership and Employee Commitment to Work In Nigeria Bottling Company. Studies in Sociology of Science. Vol. 2, No.2 pp $62-68$

[2.] Ambali, A.R.,Suleiman, G.E.,Bakar, A.N.,Hashim, R.\& Tariq,Z. (2010) Servant leadership's values and staff's commitment: policy implementation focus. American Journal of Scientific Research. Issue 13 (2011) pp. 18 - 40

[3.] Amy Lyman (2012) Trustworthy Leader; Leveraging the Power of Trust to Transform your Organization. Jossey Bass N.J U.S.A

[4.] Barbuto, J. E., \& Wheeler, D. W. (2006b). Scale development and construct clarification of servant leadership. Group \& Organization Management, 31(3), 300-326.

[5.] Barnett, T. M. (2011) Leadership Theories and Studies: Reference for Business, Encyclopedia of Business $2^{\text {nd }}$ Edition. Retrieved January 2012 from http://www.reference from business.com/management/int-loc/leadership-Theories-and-studies.html

[6.] Bud West, G. R. \& Bocarnea, M. (2008) Servant leadership and organizational outcomes: Relationships in United States and Filipino higher educational settings. School of global leadership and entrepreneurship. Servant leadership research roundtable May 2008

[7.] Carder, J. C. (2012) The relationship between servant leadership and affective organizational commitment. Unpublished Ph.D Thesis. Indiana Wesleyan University. UMI Number 3602281

[8.] Dennis, R.S., \& Winston, B.E. (2003). A factor analysis of page and wong's servant leadership instrument. Leadership \& Organization Development Journal, 24(8), 455-459.

[9.] Dennis, R. S., \& Bocarnea, M. (2005). Development of the servant leadership assessment instrument. Leadership \& Organization Development Journal, 26(8), 600-615.

[10.] De Pree, M. (1992) Leadership Jazz, Currency - Doubleday, New York, NY.

[11.] De Pree, M. (1997) Leading Without Power: Finding Hope in Serving Community. Jossey - Bass, San Francisco, CA

[12.] Earnhardt, M. P. (2008) Testing a servant leadership theory among United States military membersRetrievedJune212013fromhttp://www.regent.edu/acad/global/publications/elj/vol1iss2/ELJ_V1Is2_Earnhardt.pdf

[13.] Ehrhart, M. G. (2004). Leadership and procedural justice climate as antecedents of unit-level organizational citizenship behavior. Personnel Psychology, 57(1), 61-94.

[14.] Farling, M. L., Stone, A. G., \& Winston, B. E. (1999). Servant leadership: Setting the stage for empirical research. Journal of Leadership Studies, 6(1/2), 49-72.

[15.] Ferch, S. (2005). Servant-leadership, forgiveness, and social justice. International Journal of Servant Leadership, 1(1), 97 - 113

[16.] Greenleaf, R. K. (1977). Servant leadership: A journey into the nature of legitimate power and greatness. New York: Paulist Press.

[17.] Hale, J. R. \& Fields, D. (2007) Exploring servant leadership across cultures: A study of $\quad$ followers in Ghana and the USA. Leadership 2007, 3(4), $397-417$

[18.] Kouzes, J. M. and Posner, B. Z. (1993) Credibility: How Leaders Gain and Lose It, Why People Demand It. Jossey-Bass.San Francisco

[19.] Laub, J. (1999) Assessing the servant organisation: Development of the servant organizational leadership assessment (SOLA) instrument. Unpublished doctoral dissertation. Florida Atlantic University, Boca Raton, FL

[20.] Liden, R. C., Wayne, S. J., Zhao, H., and Henderson, D. (2008). Servant leadership: Development of a multidimensional measure and multi-level assessment. The Leadership Quarterly, 19, 161-177.

[21.] Lubin, K. A. (2001) Visionary Leader Behaviours and Their Congruency with Servant Leadership Characteristics. Dissertation Abstracts International, 62(08), 2645, (UMI No. 3022943) 
[22.] Mazarei, E.,Hoshyar, M. \& Nourbakhsh,P. (2013) The relationship between servant leadership style and organizational commitment. Archives of Applied Science Research, 5 (1): 312- 317

[23.] Mahembe, B., and Engelbrecht, A.S. (2013). The relationship between servant leadership, affective team commitment and team effectiveness. SA Journal of Human Resource Management 11 (1)

[24.] McMinn, T. F. (2001), "The Conceptualization and Perception of Biblical Servant Leadership in the Southern Baptist Convention", Digital Dissertations, 3007038

[25.] Northouse, P.G. (2007) Leadership Theory and Practice $4^{\text {th }}$ Edition. Sage Publications. London

[26.] Page, D., and Wong, T. P. (2000). A conceptual framework for measuring servant-leadership. In S. Adjibolosoo (Ed.), The human factor in shaping the course of history and development. (pp. 69-110). Lanham, MD: University Press of America.

[27.] Patterson, K. A. (2003). Servant leadership: A theoretical model. Retreived June 21, 2013 from http://www.regent.edu/acad/global/publications/sl proceedings/2003/patterson servant leadership.pdf

[28.] Peterson, S. J. \& Galvin, B. M. (2012) CEO servant leadership: Exploring executive characteristics and firm performance. Personnel psychology, 2012, 65, 565-596

[29.] Russell, R. F. and Stone, A. G. (2002) A Review of Servant Leadership Attributes: Developing a Practical Model. Leadership and Organization Development Journal 23(3), 145 - 157

[30.] Sendjaya, S. and Sarros, J.C. (2002) Servant Leadership: Its Origin, Development and Application in Organizations. Journal of Leadership and Organizational Studies 9(2) $57-64$

[31.] Sendjaya, S., Sarros, J.C., \& Santora, J.C. (2008). Defining and measuring servant leadership behaviour in organizations. Journal of Management Studies, 45(2), 402-424

[32.] Shiri, H., Zahed, B., \& Sattari, S. (2014) Investigating the Condition of Leadership Styles of High School Managers of the City of Ardabil from Teacher's Viewpoint. Applied Psychology, 5: 1 -9

[33.] Spears, L. C. (2002). Tracing the Past, Present, and Future of Servant-Leadership. In Focus On Leadership: Servant-leadership for the Twenty-first Century (pp. 1-10). New York, NY: John Wiley and Sons, Inc

[34.] Stefánsdóttir, K. H. (2013) Are there signs of a better organizational performance in the presence of servant leadership? Unpublished Thesis. Reykjavik University Spring 2013, 280974 - 4399

[35.] Stone, A. G., Russell, R. F., and Patterson, K. (2004). Transformational versus servant leadership: A difference in leader focus. The Leadership \& Organization Development Journal, 25(4), 349-361.

[36.] Taleghani, M. \& Mehr, R. R. (2013) The relationship between servant leadership and organizational citizenship behaviour in executive organizations of Guilan Province. Journal of Basic and Applied Scientific Research 3(1), 910 - 917

[37.] Taylor, T. A. (2002). Examination of Leadership Practices of Principals Identified as Servant Leaders. Dissertation Abstracts International, 63 (05), 1661. (UMI No.3052221)

[38.] Thakore, D. (2013) Servant Leadership. International Letters of Social and Humanistic Sciences 7(2013) 23 - 32 ISSN 2300 2697

[39.] Van Dierendonck (2011) Six key servant leadership attributes. Retrieved June 23, 2013 from http://www.iedp.com/Blog/six key servant leadership attributes.

[40.] Van Dierendonck, D. (2011). Servant leadership: A review and synthesis. Journal of Management, 37(4), 1228-1261. http://dx.doi.org/10.1177/0149206310380462

[41.] Van Dierendonck \& Nuijten, I. (2011) The Servant Leadership Survey: Development and validation of a Multidimensional Measure. J Bus Psychol (2011) 26:249-267 DOI 10.1007/ s10869-010-9194-1

[42.] Walker, J. (2003). A new call to stewardship and servant leadership. Nonprofit World, 21(4), 25.

[43.] Wei, L. S. \& Desa, N. M. (2013) Servant leadership and organizational commitment: An empirical evidence from banking industry in Malaysia. $4^{\text {th }}$ International conference on business and economic research $\left(4^{\text {th }}\right.$ ICBER 2013)

[44.] Wheeler, D. W. (2011) Leadership for High Education; Principles and Practices. Jossey Bass U.S.A (Hoboken, N.J U.S.A)

[45.] Winston, B. E. (2003). Extending Patterson's servant leadership model. Retrieved June 21, 2013, from http://www.regent.edu/acad/global/publications/sl_proceedings/2003/ winston_extending_patterson.pdf

[46.] Wong, P.T. and Davey, D. (2007) Best Practices in Servant Leadership. School of Global Leadership \& Entrepreneurship. Paper presented at Regent University's. Leadership Roundtable,Retrieved21,June,2013fromhttp://www.regent.edu/acad/global/publications/sl_proceedings/2007/wong-davey/pdf

[47.] Yong, B, (2013) Relationship between emotional intelligence, motivation, integrity, spirituality, mentoring and servant leadership practices. Arts and Social Sciences Journal, Vol.2013: ASSJ - 67

[48.] Zhang, H., Kwan, H.K., Andre, M., Everett, M., \& Jian, Z. (2011) Servant leadership, organizational identification and work to family enrichment: The moderating role of work climate for Sharing family concerns Human resource management, September - October 2012, Vol. 51 No. 5 pp. 747 - 768 